\title{
Research on Educational Reform of Higher Vocational Colleges Guided by Information Technology
}

\author{
Jianwei Xiao \\ Navigation Department \\ Tianjin Maritime College \\ Tianjin, China
}

\author{
Rukai Zhang* \\ Navigation Department \\ Tianjin Maritime College \\ Tianjin, China
}

\begin{abstract}
With the development of China's economy and the advancement of science and technology, the information age comes. Higher vocational education has encountered many challenges while gaining opportunities. Therefore, this paper analyzes the application of online open curriculum construction and information-based teaching reform in higher vocational colleges. This paper mainly focuses on how informationization can help the self-study of higher vocational students, conducts certain discussion and analysis in this era background. The training of practical courses is a necessary way to train highquality technical and skilled talents in higher vocational colleges. Through the reform of the teaching methods of practical training courses, the informatization teaching of practical training courses is intensified, and the Internet training platform and handheld learning are adopted. The combination of platform, multimedia information technology and traditional blackboard-books will reform the teaching methods of training courses, give full play to the advantages of teaching resources and information-based teaching, accelerate the process of reforming the informationbased teaching methods of higher vocational colleges, and improve the quality of professional and technical personnel training.
\end{abstract}

Keywords-informationization; education reform; practical training

\section{INTRODUCTION}

It is an important issue to improve people's overall cultural knowledge. Of course, the times are constantly improving, and there is a certain change in the way of teaching. This change is informationization. In the context of this era, students can get better learning resources and expand the way to learn. This is not only a manifestation of learning knowledge, but also a great improvement in the ability of students ${ }^{[1]}$. Therefore, how to use information technology to better support students' learning, or to continue to develop and explore in the future.

\section{The CURRENT StATUS OF Higher Vocational STUDENTS}

Some problems that arise during the student's learning process. Before the actual use of informational teaching, many areas use traditional teaching methods. Students have no way to become interested in learning, and it is more likely to be

This paper was supported by the project of Tianjin Higher Vocational and Technical Education Research Association (No. XVIII 4094), and the project of Journal of Tianjin Vocational Institutes (No. XHXB2019B025). unable to keep up with the teacher's lectures. The main way for students to acquire knowledge is through the teacher's explanation in the classroom. If you encounter problems during the learning process, you can only ask the teacher for help. In addition, the number of teachers is limited; so many students' problems are not solved in a timely manner, and eventually the problem accumulation. Prolonged development may cause students to get bored with this subject ${ }^{[2]}$.

\section{THE RELATIONSHIP BETWEEN INFORMATIONIZATION AND VOCATIONAL STUDENTS' LEARNING}

\section{A. The basic situation of self-learning ability of higher vocational students}

For many vocational school students, their performance may not be particularly good. Therefore, it may be relatively weak for self-learning ability. They may not have a very clear direction for their own learning, so it is difficult to establish a learning goal to help them learn. In fact, a large part of the reason for the poor autonomy of students in higher vocational colleges is due to the traditional teaching mode of our country. Under this model, the students only mechanically store the knowledge that the teacher taught them in their brains. Some knowledge is not even understood at all. It can be said that there is no fun at all. And the knowledge that is passively accepted is actually hard to be grasped by the students. Education in China has always been a topic of great concern. Because many schools are fixed knowledge and fixed answers when they take the exam. This also causes students to memorize knowledge in the textbook and not understand it. In this way, they can also easily get high scores, even higher than those who actually understand. Therefore, they are even less able to learn independently, because they are completely unnecessary.

\section{B. Informatization and self-study of vocational students}

The so-called self-learning ability of students is actually that they can choose one aspect they will learn through their own consciousness, and this kind of learning is arranged according to their own decisions. Of course, the decision they make must also be the correct way to learn, and relying on informatization can provide students with such a platform to improve their ability to be independent. In terms of education, 
the continuous development of information technology has enabled much knowledge to be queried on the Internet and truly shared. This broadens the way students learn in higher vocational colleges, not only relying on the teacher's classroom explanation, but also able to solve some of the learning problems they encounter on the Internet. Realize yourself to grasp the progress of your own learning, as well as some targeted exercises $^{[3]}$. For a long time, they have been able to invisibly develop their ability to learn independently. For the study of vocational students, the students' interest in learning is an important aspect of determining whether they can learn this course well. The integration of information technology can be said to provide them with such a platform. For some very abstract mathematical knowledge, you can also show it through some pictures or interesting small videos. In this case, it is more conducive to students' understanding of this abstract knowledge, so that they can learn and master later.

\section{Changes in student self-learning in the context of informationization}

Through the transformation of traditional teaching methods, it also brings some new ways for the students of higher vocational education. In the new teaching process, students can be the most central figure in the whole classroom. This increases the students' initiative in learning and changes the way they passively accept the knowledge taught by the teacher. It also changed the use of traditional textbooks to impart knowledge and make more use of information technology to provide students with more interesting classrooms. Through the visualization of the knowledge points, it is convenient for students to understand and achieve the purpose of attracting students' attention.

\section{Informatization on the teaching development of higher vocational colleges}

It is necessary to promote the information-based teaching model in higher vocational colleges in various regions. In order to prevent teachers from understanding the information technology and hinder the teaching, teachers should be given adequate guidance to the teachers in the vocational colleges, so that they can truly understand the information technology and master the use of information technology so that they can skillfully Use in class. The school can also establish a unique learning platform for the teaching of the school, fully realize the sharing of learning resources, and gradually establish a complete learning system. This will enable students to learn independently, expand their knowledge and improve their ability to learn independently.

\section{ONLINE Open COURSE CONSTRUCTION}

With the development of society and the progress of the times, "Internet +" has gradually become the basis and platform for China's major policies, and has also incorporated information education into the development strategy of education. The Ministry of Education has clearly pointed out that vocational education should use modern information technology to comprehensively transform traditional teaching and focus on handling the problems in practical training. As an important way to cultivate talents, higher vocational education should innovate in scientific research, personnel training, cultural inheritance, social services and other aspects, improve the level of running schools, and achieve high-skilled personnel education. Online open courses play an important role in informatization teaching, especially in the era of "Internet +", the status and role become more and more obvious. In the process of building a resource library for higher vocational education, the online open course shoulders the role of support points. The importance of it is self-evident. Only by using the curriculum can a complete resource system be formed, which will enable China's higher vocational education to develop more rapidly.

\section{A. Development Status and Problems of Online Open Courses in Higher Vocational Colleges}

Coexistence of traditional classroom teaching and online open course application. At present, the teaching mode adopted by majority higher vocational colleges is still a traditional teaching method. With the development of science and technology, the construction of online open courses will have a greater impact on traditional teaching. At this stage, although higher vocational colleges have also shifted their teaching focus to the construction of online open courses, due to the impact of their traditional teaching, it is difficult to carry out informatization teaching in a short time ${ }^{[4]}$. Only a few public courses have tried this model, and this teaching method has not received good results due to the lack of good interaction between teachers and students.

The teaching management system is solidified and it is difficult to adapt to the online teaching of open courses. The teaching methods, contents, credits and other contents in traditional teaching are all static, and different majors have the same strict requirements for credits and courses. The teaching methods are mostly concentrated. In contrast, online open courses can break the shackles of traditional teaching through novel teaching modes such as micro video and flip classroom. Higher vocational colleges can combine online theoretical learning with offline practical activities through online open courses to achieve a hybrid teaching model. Students can repeatedly watch online content; communicate with students and teachers in real time, and help. Teachers timely grasp the students' understanding of knowledge ${ }^{[5]}$. However, the current teaching management can't match the mixed teaching mode, which poses great challenges to online assessment, student selection, information application, and improvement of teaching quality.

\section{B. Higher vocational online open courses lead the reform of informational teaching mode}

- Change the traditional teaching mode to adapt to informational teaching. Due to the influence of traditional ideas, teachers are more likely to be the dominant players in the classroom, ignoring the students' central position, so that they can't mobilize the students' enthusiasm for learning, and can't achieve good teaching results. With the development of information technology, notebook computers, smart phones, etc. have become a necessity for life, providing a broader space for information teaching. The 
construction of online open courses is inseparable from the support of information-based instructional design, the transformation of traditional teaching modes, the return of the main body of the classroom to students, and the formation of a teaching model based on students and teachers. Higher vocational colleges can realize the hybrid teaching mode through online open courses, combine online theoretical learning with offline practical activities, realize the good interaction between students and teachers, give play to students' subjective initiative, and enable students to have the ability of digital learning ${ }^{[6-7]}$

- Create a flexible teaching management mechanism to improve the level of informatization teaching. The application of online open curriculum construction and informatization teaching in higher vocational colleges should break away from the shackles of traditional teaching management and teaching methods. Because of hybrid teaching, it is necessary to re-adjust the allocation of learning time, curriculum, and assessment methods. The construction of online open courses is mainly based on team teaching. There will be more than one teacher in one course. Different course teams should coordinate with each other and arrange working hours reasonably. The teaching problems arising from the application of online open courses construction and information-based teaching in higher vocational education are worthy of our consideration. We break the traditional credit management system, establish a new credit system, break the traditional teaching mode, and form a new team to teach, even break The old pattern and the formation of a new pattern are inseparable from the full support of a sound teaching management mechanism.

- Promote education by teaching and improve teachers' informatization teaching ability. The level of teachers' informatization teaching in higher vocational colleges is mainly reflected in three aspects: information technology application ability, professional post vocational skills and teaching ability. The online open curriculum construction curriculum team should participate in research and development, construction and other content throughout the whole process, and use the curriculum construction to provide professional competence, curriculum design ability and information technology use ability, and regularly carry out training activities to provide a broader development platform for teachers' information teaching.

\section{IMPLEMENTATION OF TEACHING SOLUTIONS BASED ON INFORMATION TECHNOLOGY}

\section{A. Analysis of the problems in the teaching of traditional training courses}

The vocational training is based on skill training, while the traditional training course is taught by a teacher. The students are 50 people. The students can't see clearly, they can't see the key, and the practical teaching effect is poor. The traditional training course is "teacher Center", the students follow the teacher, the interaction between the students is less; the practice course instrument is complicated to operate, the skill requirements are high, the traditional practice teaching, the students watch the "live", do not know the key, listen to the key, when they operate the instrument Remember that the operation method is impossible to start, the training effect is poor; the traditional practice teaching is the unified demonstration skill operation by the training instructor, the students can't choose their favorite teaching methods and contents according to their own interests and habits, and the teacher is also difficult to change their own. Teaching habits to meet all students, this traditional teaching method is likely to cause teacher teaching and student learning mismatch, the classroom is less attractive to students, and ultimately lead to poor student learning.

\section{B. Improvement of traditional training courses}

- Based on the "information-based teaching method", the teaching design of the practical training course of higher vocational colleges is a necessary and effective condition for ensuring and promoting the effective development of information-based teaching of practical courses. First of all, the teaching situation analysis, training instructors from the student source, major, grade, knowledge preparation, characteristics and other aspects of detailed investigation and analysis, to understand the situation of students in the teaching class, to lay the foundation for teaching design. Secondly, the content of the teaching should be selected, and the teaching content should be suitable for students' learning, difficulty, and reasonable decomposition of the teaching content into granulated skill points, which are compatible with the information-based teaching methods. Thirdly, the design of teaching activities, comprehensive design of teaching activities from before, during and after class, to achieve "doing middle school, learning in school, teaching and doing one".

- Reforming teaching methods and innovating information-based teaching methods In the process of training courses, in addition to traditional blackboards, it is necessary to make full use of the network, search engines, literature search tools, multimedia, fictional real VR, strengthen actual AR, hybrid Actual MR and holographic projection, etc. Through the integrated information teaching method of blackboard, multimedia and virtual simulation, not only can the output of teaching information be increased, but also the knowledge from the plane-stereo-dynamic-virtual reality, the abstract, difficult to understand knowledge, multi-dimensional presentation Students, students gain more direct, active and efficient knowledge.

- Based on the "information-based teaching method", the construction of the teaching resources library of the vocational training courses of higher vocational colleges and universities is based on the different learning stages and learning characteristics of students, and tailors the training resources of the training courses to decompose the training process into Granular skill points, granulated micro-courses (2 to 5 minutes video), flash animations, software simulators, digital models, e- 
courseware, literature and more. The training course teaching resource library provides students and teachers with rich and complete information resources. In terms of students, "Internet + Education" is mobile learning anytime and anywhere.

- Construct a practical teaching platform based on "information-based teaching method" In order to provide students with a better learning experience, develop a training platform based on "informationbased teaching methods", so that teachers can easily construct and publish course tasks. Organize the learner's learning process and establish a course learning assessment mechanism. Students can freely search video learning resources, complete the teacher's arranged learning content, freely control the learning progress, and use advanced methods to learn and effectively improve student autonomy. The enthusiasm of learning, improve the quality of teaching, realize personalized teaching methods, and provide students with convenient and fast mobile learning services.

\section{CONCLUSION}

With the continuous development of information technology, higher vocational education has encountered many challenges while welcoming opportunities. China is also increasing its support to help higher vocational colleges obtain better development space. The application of online open curriculum construction and informatization teaching has injected new vitality into higher vocational education, which not only satisfies the demand for education in the era of "Internet +", but also accelerates the reform of traditional teaching mode and enables information teaching in higher vocational colleges. The level has been further improved. It is not difficult to see the importance of information technology for the self-learning ability of higher vocational students. Therefore, if we want to further improve the learning ability of our students, we must promote the further development of information technology. In the future, what kind of development of information technology will be in the end is still difficult to estimate, and this requires further research and research by researchers.

\section{REFERENCES}

[1] Zhao Xiufeng. Application of Information Network Teaching in College Teaching [J]. PC Fan, 2018 (11): 216. (In Chinese)

[2] Wang Xueying. Innovation and practice of the integration of informational teaching and skill training in higher vocational colleges [J] Shandong Industrial Technology, 2018 (23): 232, 204. (In Chinese)

[3] Wang Shuang. The application of information-based teaching in the teaching of higher vocational colleges in engineering [J]. The Science Education Article Collects (late issue), 2018 (10): 110-111. (In Chinese)

[4] Zhao Likun. Discussion on the Reform of Computer Basic Teaching Based on Blue Ink Cloud Classes[J]. China New Telecommunications, 2018. (In Chinese)

[5] Ying Wei. Consolidate the solid foundation of the government's digital transformation [J]. Zhejiang Economy, 2018. (In Chinese)

[6] Shi Shimei. Research and design of information learning environment in colleges and universities[J]. Beijing: Beijing Institute of Technology, 2015. (In Chinese)

[7] Yang Tonghua. Research on the Cultivation of Autonomous Learning Ability of Higher Vocational Students in Information Technology Environment[J].Dalian: Northeast Normal University, 2016. (In Chinese) 